\title{
Efficacy and safety of 1-day versus 3-day dexamethasone for the prophylaxis of chemotherapy-induced nausea and vomiting: a systematic review and meta-analysis of randomized controlled trials
}

\author{
Ronald Chow ${ }^{1}$, David G. Warr ${ }^{2}$, Rudolph M. Navari ${ }^{3}$, May Tsao ${ }^{1}$, Milica Milakovic ${ }^{1}$, Marko Popovic ${ }^{1}$, \\ Leonard Chiu ${ }^{1}$, Henry Lam ${ }^{1}$, Carlo DeAngelis ${ }^{1,4}$ \\ ${ }^{1}$ Odette Cancer Centre, Sunnybrook Health Sciences Centre, ${ }^{2}$ Princess Margaret Cancer Centre, University of Toronto, Toronto, Canada; \\ ${ }^{3}$ University of Alabama Birmingham School of Medicine, Birmingham, USA; ${ }^{4}$ Leslie Dan Faculty of Pharmacy, University of Toronto, Toronto, \\ Canada \\ Contributions: (I) Conception and design: R Chow, RM Navari, C DeAngelis; (II) Administrative support: R Chow; (III) Provision of study material or \\ patients: R Chow, H Lam; (IV) Collection and assembly of data: R Chow, M Milakovic, M Popovic; (V) Data analysis and interpretation: R Chow; (VI) \\ Manuscript writing: All authors; (VII) Final approval of manuscript: All authors. \\ Correspondence to: Ronald Chow. Care of Dr Carlo DeAngelis, Sunnybrook Health Sciences Centre, 2075 Bayview Avenue, Toronto, ON M4N 3M5, \\ Canada. Email: rchow48@uwo.ca.
}

Background: Dexamethasone is typically administered for multiple days after the start of chemotherapy to prevent delayed chemotherapy-induced nausea and vomiting (CINV). Frequent administration of corticosteroids has been associated with problematic side effects. Reducing the dose and frequency of corticosteroids administered during chemotherapy treatment may be beneficial in reducing the side effects experienced by patients, as long as it is possible to maintain its efficacy in the prophylaxis of CINV. The purpose of the review and meta-analysis is to compare the safety and efficacy of multi-day versus 1-day regimen of dexamethasone.

Methods: A comprehensive literature search was carried out in Ovid MEDLINE, Embase and the Cochrane Central Register of Controlled Trials. The primary endpoints were the proportion of patients achieving complete response and complete control in the acute, delayed and overall phases. Secondary endpoints were the percentage of patients who experienced no nausea, no emesis, no use of rescue medication, no adverse events, no constipation, no headache and no fatigue/insomnia.

Results: Seven randomized controlled trials (RCTs) were included in this meta-analysis, and a total of 659 and 649 patients were randomized to receive dexamethasone on 1 day and 3 days, respectively. The two treatments were equivalent in 16 of 17 endpoints.

Conclusions: Despite the paucity of data in this setting, we find that the 1-day dexamethasone therapy provides a similar efficacy and safety profile as a treatment of 3-day dexamethasone in the prophylaxis of CINV. The similarities in efficacy and safety of the two interventions suggests that 1-day dexamethasone can be administered as an alternative to 3 days.

Keywords: Chemotherapy-induced nausea and vomiting (CINV); efficacy; safety; dexamethasone

Received: 01 April 2018; Accepted: 13 April 2018; Published: 28 May 2018.

doi: 10.21037/jhmhp.2018.04.05

View this article at: http://dx.doi.org/10.21037/jhmhp.2018.04.05 


\section{Introduction}

Chemotherapy-induced nausea and vomiting (CINV) can result in deterioration in a patient's quality of life and consequently lead to poorer compliance with further treatment (1-3). It is typically reported as occurring in the acute ( $0-24$ hours post-chemotherapy) or delayed (24-120 hours post-chemotherapy) phases, and is known to cause dehydration and malnutrition (4-6).

To protect against CINV, many different types of antiemetics have been developed to inhibit pathways presumed to be associated with CINV (7). Palonosetron, ondansetron and granisetron are 5-hydroxytrypatmine type 3 receptor antagonists $\left(5-\mathrm{HT}_{3} \mathrm{RAs}\right)$ that aim to disrupt the process of serotonin from enterochromaffin cells binding to $5-\mathrm{HT}_{3}$ receptors $(7,8)$. Other antiemetics such as aprepitant, netupitant and rolapitant are neurokinin-1 receptor antagonists $\left(\mathrm{NK}_{1} \mathrm{RA}\right)$ that are designed to block substance $\mathrm{P}$ from initiating impulses to the vomiting centre in the medulla $(9,10)$.

A meta-analysis by Ioannidis et al. found that dexamethasone in conjunction with other antiemetics is superior to placebo with respect to complete protection (11). Combination therapy of antiemetics with dexamethasone has now become the standard of care for preventing CINV in patients receiving moderately emetogenic chemotherapy (MEC) and highly emetogenic chemotherapy (HEC), and the recommended line of therapy by the Multinational Association of Supportive Care in Cancer (MASCC) and European Society of Medical Oncology (ESMO) antiemetic guidelines (12).

Dexamethasone is typically administered for multiple days after the start of chemotherapy to help treat delayed CINV (13). However, frequent administration of corticosteroids has been associated with problematic side effects such as edema, bulimia, weight gain, digestive disorders, hyperglycemia and reactivation of the hepatitis $B$ virus (14-16). Reducing the duration that steroids are administered during chemotherapy treatment may be beneficial in reducing the side effects experienced by patients, while at the same time potentially maintaining efficacy. The aim of our meta-analysis is to compare the safety and efficacy of multi-day versus 1-day regimens of dexamethasone in this setting.

\section{Methods}

\section{Search strategy}

A comprehensive literature search was carried out in Ovid MEDLINE, Embase and Cochrane Central Register of Controlled Trials. Key words included "neoplasms", "dexamethasone", "nausea", and "vomiting". The search was limited to English-language randomized controlled trials (RCTs) (Appendix 1). Reference lists of articles included in this review were also hand-searched to identify any further relevant literature.

\section{Selection criteria}

Studies were screened by title and abstract, and identified for full-text screening if they performed a head-to-head comparison of dexamethasone administered on day 1 relative to days $1-3$ of chemotherapy in a RCT full-text articles were eligible for quantitative synthesis if they reported on at least one of the following endpoints in either the acute (0-24 hours post-chemotherapy), delayed (24-120 hours post-chemotherapy) or overall phases for cycle 1 :

(I) Complete response (CR)—no emesis and no use of rescue medication;

(II) Complete control (CC) — no emesis, no use of rescue medication and no more than mild nausea;

(III) No nausea;

(IV) No emesis—no episodes of vomiting or retching;

(V) No use of rescue medication;

(VI) No adverse events-no episodes of treatmentrelated adverse events;

(VII) No constipation;

(VIII) No headache;

(IX) No fatigue/insomnia;

Studies were excluded if they were duplicates of other articles, were non-original research reports, or were small trials (<ten patients).

\section{Data extraction and endpoints}

The primary endpoints were the proportion of patients achieving CR and CC in the acute, delayed and overall phases, as reported by study authors. Secondary endpoints were the proportion of patients who experienced no nausea, 


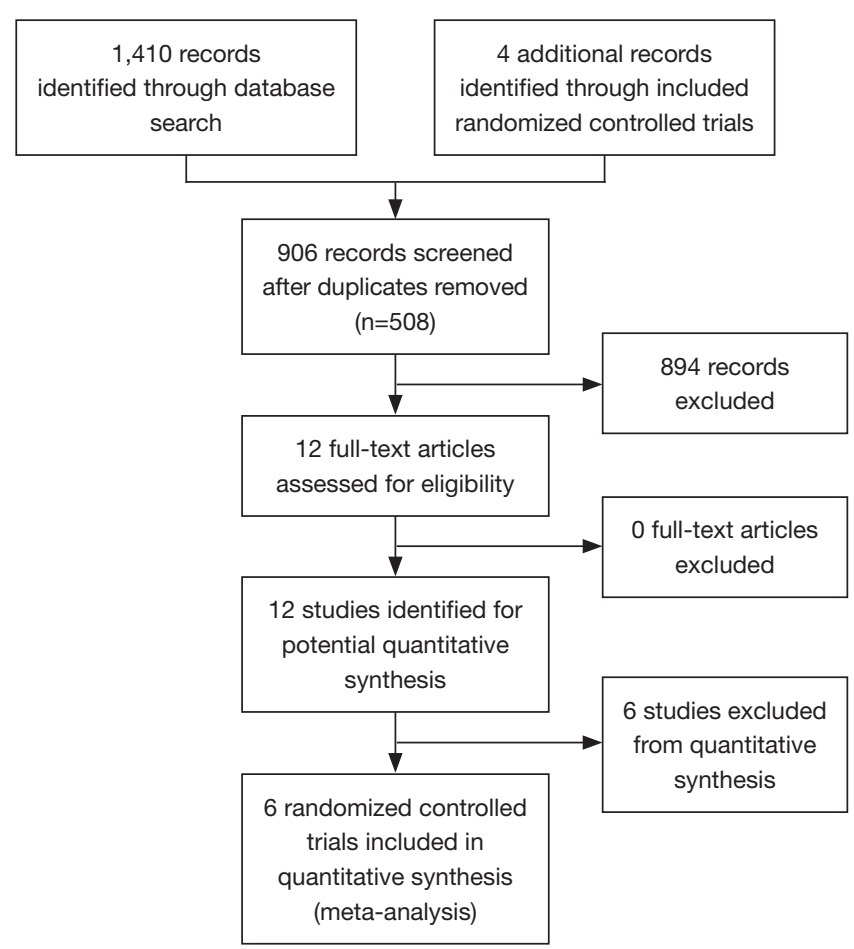

Figure 1 PRISMA flow diagram.

no emesis, no use of rescue medication, no treatment-related adverse events and no constipation. The "nausea" endpoint in the overall phase and "rescue medication" endpoints in the acute phase were not recorded, as only one study reported on each of these endpoints in their respective phase.

\section{Statistical analyses}

To perform the meta-analysis, a Mantel-Haenszel method with a random-effects analysis model was used to compute odds ratios (OR) and accompanying $95 \%$ confidence intervals $(\mathrm{CI})$. $\mathrm{P}$ values less than 0.05 were considered significant with regards to the test for overall effect. All analyses were conducted using Review Manager (RevMan 5.3) by Cochrane IMS.

\section{Results}

From the 1,414 records identified from the search, 906 were screened at the title $\&$ abstract level after duplicates $(\mathrm{n}=508)$ were removed. Of the 12 full-text articles assessed for eligibility, seven RCTs $(13,17-22)$ were included for this meta-analysis (Figure 1). For consistency in endpoints, two studies were excluded because delayed phase was defined as 2 to 6 days following treatment, rather than 2 to 5 days $(23,24)$. A total of 659 and 649 patients were randomized to receive dexamethasone on 1 and 3 days, respectively.

Only two studies recruited patients who were treated with HEC, while the other five contained patients treated with MEC. The number of patients randomized to each intervention arm ranged from 39 to 166 . All but two studies recruited exclusively female patients, and all but one only recruited patients who were chemotherapy-naïve. Other characteristics of included RCTs are displayed in Table 1.

\section{Efficacy-CR and CC}

Six studies documented rates of CR, and five studies reported on CC. CR in the acute phase was approximately equivalent between 1-day and multi-day dexamethasone (OR, 0.90; 95\% CI, 0.64-1.26). The two treatment arms were similar in terms of CR in the delayed (OR, 1.18; $95 \%$ CI, 0.92-1.51) and overall (OR, 1.07; 95\% CI, 0.84-1.37) phases (Figure 2). Three-day dexamethasone treatment was not superior to 1-day dexamethasone treatment with respect to $\mathrm{CC}$ in the acute (OR, 0.78 ; 95\% CI, 0.51-1.19), delayed (OR, 1.17; 95\% CI, 0.89-1.56) and overall (OR, 1.03; 95\% CI, 0.78-1.35) phases (Figure 3).

\section{Efficacy-no nausea, no emesis and no use of rescue medication}

Only three studies recorded nausea in the acute and delayed phases. The analysis revealed that 1-day treatment was equivalent to 3-day treatment (Figure S1). The two interventions also yielded similar control of emesis in the acute, delayed and overall phases (Figure S2). A noticeably larger proportion of patients receiving 1-day dexamethasone treatment required rescue medication in the delayed phase; no similar finding was reported in the overall phase (Figure S3).

\section{Safety}

Five six studies reported on adverse events. Patients treated with 1-day and 3-day treatment were equally as likely to develop adverse events (OR, 0.88; 95\% CI, 0.66-1.16). One-day dexamethasone was equally as safe as 3 -day dexamethasone treatment in terms of constipation (OR, 0.72; 95\% CI, 0.45-1.14), headaches (OR, 1.16; 95\% CI, 0.69-1.95) and fatigue/insomnia (OR, 1.71; 
Table 1 Characteristics of randomized controlled trials included in meta-analysis

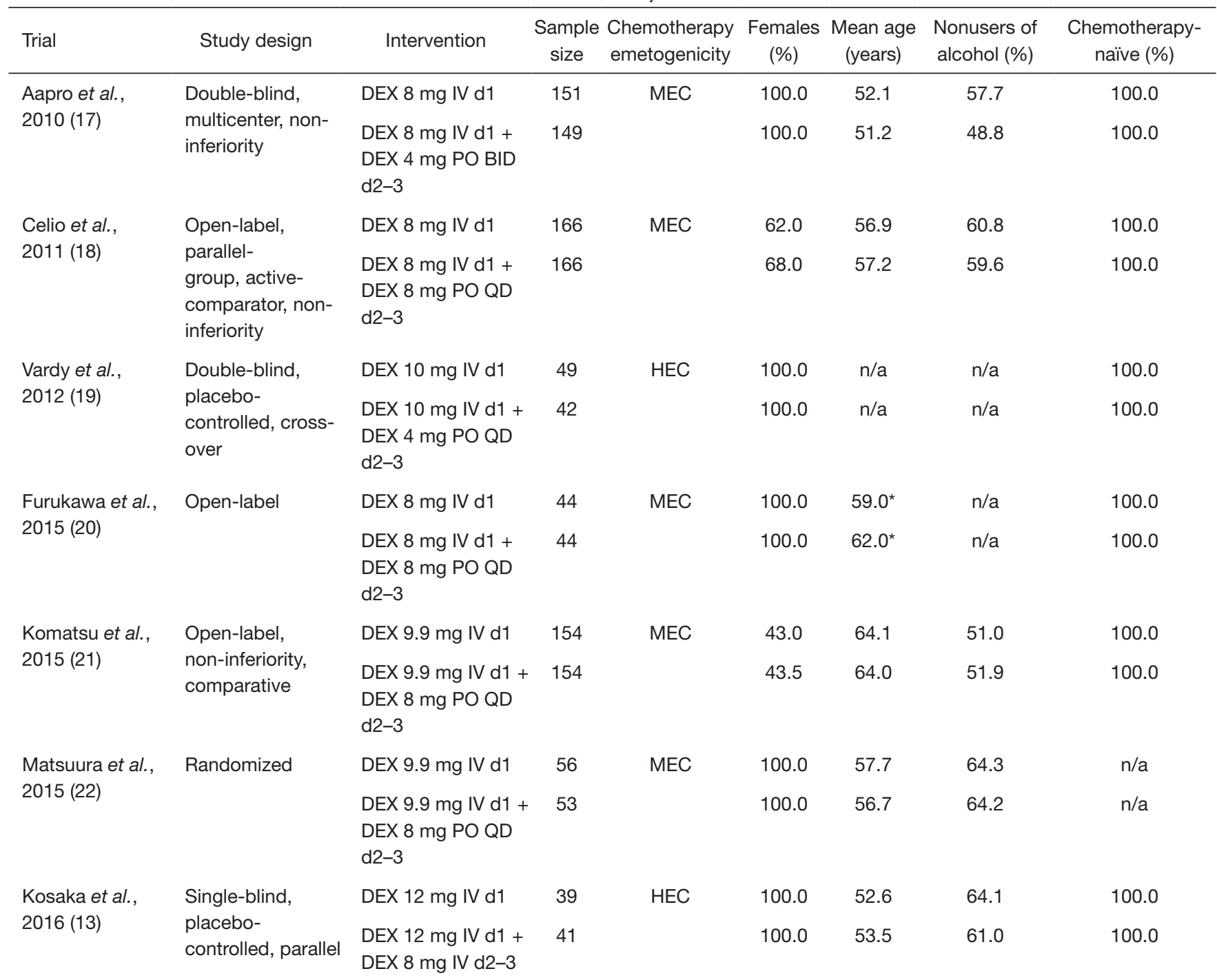

*, median age. BID, bis in die; D, day; DEX, dexamethasone; HEC, highly emetogenic chemotherapy; IV, intravenously; MEC, moderately emetogenic chemotherapy; n/a, data not available or extractable; PO, per os; QD, quaque die.

95\% CI, 0.83-3.53) (Figure S4).

\section{Discussion}

This is the first meta-analysis to our knowledge to investigate the efficacy and safety of 1-day versus multi-day dexamethasone treatment for the prophylaxis of CINV in combination with antiemetics.

The efficacy of dexamethasone administered on day 1 is equivalent to the efficacy of dexamethasone administered on days 1-3; the efficacy and safety were identical in 16 of 17 endpoints. The suggestion by Roscoe et al. (25) that the 3-day regimen is superior with respect to control of delayed nausea was not found in the present analysis-it is important to note that these conclusions are made on the basis of two included trials, and more studies should investigate these conflicting conclusions. The two treatments are also similar with respect to safety, specifically constipation, headache and fatigue/insomnia.

There were only seven studies in this review, of which five were studies recruiting only MEC patients. Future studies should further investigate the two dexamethasone arms in the HEC setting to see whether there are similar conclusions.

The similarities in efficacy and safety of the two 


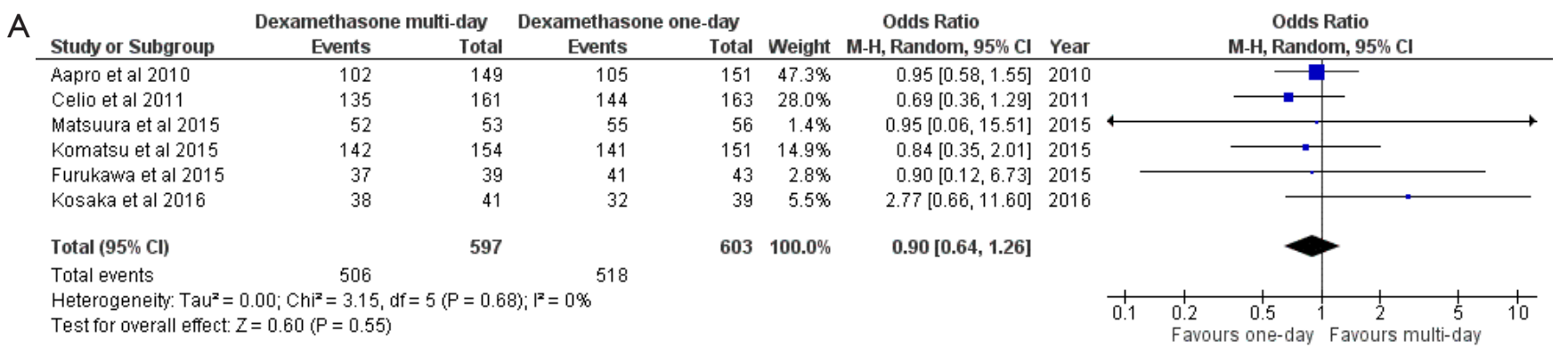

B

\begin{tabular}{|c|c|c|c|c|c|c|c|c|c|}
\hline \multirow[b]{2}{*}{ Study or Subgroup } & \multicolumn{2}{|c|}{ Dexamethasone multi-day } & \multicolumn{2}{|c|}{ Dexamethasone one-day } & \multicolumn{3}{|c|}{ Odds Ratio } & \multirow{2}{*}{\multicolumn{2}{|c|}{$\begin{array}{c}\text { Odds Ratio } \\
\text { M-H, Random, } 95 \% \mathrm{Cl}\end{array}$}} \\
\hline & Events & Total & Events & Total & Weight & M-H, Random, 95\% Cl & Year & & \\
\hline Aapro et al 2010 & 98 & 149 & 94 & 151 & $28.0 \%$ & $1.17[0.73,1.87]$ & 2010 & & $=$ \\
\hline Celio et al 2011 & 124 & 161 & 112 & 163 & $25.5 \%$ & $1.53[0.93,2.50]$ & 2011 & & \\
\hline Matsuura et al 2015 & 36 & 53 & 34 & 56 & $10.1 \%$ & $1.37[0.62,3.01]$ & 2015 & & \\
\hline Furukawa et al 2015 & 30 & 39 & 30 & 43 & $6.4 \%$ & $1.44[0.54,3.88]$ & 2015 & & \\
\hline Komatsu et al 2015 & 100 & 154 & 101 & 151 & $27.8 \%$ & $0.92[0.57,1.47]$ & 2015 & $=$ & \\
\hline Kosaka et al 2016 & 36 & 41 & 37 & 39 & $2.2 \%$ & $0.39[0.07,2.14]$ & 2016 & $\longleftarrow$ & \\
\hline Total $(95 \% \mathrm{Cl})$ & & 597 & & 603 & $100.0 \%$ & $1.18[0.92,1.51]$ & & & \\
\hline Total events & 424 & & 408 & & & & & & \\
\hline $\begin{array}{l}\text { Heterogeneity: Tau²= } \\
\text { Test for overall effect: }\end{array}$ & $\begin{array}{l}00 ; C^{2}{ }^{2}=4.06 \\
=1.27(P=0.21\end{array}$ & $=0.5$ & 4); $\left.\right|^{2}=0 \%$ & & & & & $\begin{array}{cc}0.5 & 0.7\end{array}$ & $\begin{array}{c}1.5 \\
\text { Favours m }\end{array}$ \\
\hline
\end{tabular}

C

\begin{tabular}{|c|c|c|c|c|c|c|c|}
\hline \multirow[b]{2}{*}{ Study or Subgroup } & \multicolumn{2}{|c|}{ Dexamethasone multi-day } & \multicolumn{2}{|c|}{ Dexamethasone one-day } & \multicolumn{3}{|c|}{ Odds Ratio } \\
\hline & Events & Total & Events & Total & Weight & M-H, Random, $95 \% \mathrm{Cl}$ & Year \\
\hline Aapro et al 2010 & 80 & 149 & 81 & 151 & $28.0 \%$ & $1.00[0.64,1.58]$ & 2010 \\
\hline Celio et al 2011 & 113 & 161 & 109 & 163 & $26.2 \%$ & $1.17[0.73,1.87]$ & 2011 \\
\hline Furukawa et al 2015 & 30 & 39 & 29 & 43 & $6.0 \%$ & $1.61[0.60,4.29]$ & 2015 \\
\hline Komatsu et al 2015 & 98 & 154 & 100 & 151 & $26.1 \%$ & $0.89[0.56,1.43]$ & 2015 \\
\hline Matsuura et al 2015 & 36 & 53 & 34 & 56 & $9.3 \%$ & $1.37[0.62,3.01]$ & 2015 \\
\hline Kosaka et al 2016 & 34 & 41 & 32 & 39 & $4.3 \%$ & $1.06[0.34,3.37]$ & 2016 \\
\hline Total $(95 \% \mathrm{Cl})$ & & 597 & & 603 & $100.0 \%$ & $1.07[0.84,1.37]$ & \\
\hline
\end{tabular}

Total events 391385

Heterogeneity: $\operatorname{Tau}^{2}=0.00 ; \mathrm{Chi}^{2}=1.82, \mathrm{df}=5(\mathrm{P}=0.87) ; \mathrm{I}^{2}=0 \%$

Test for overall effect: $Z=0.59(P=0.56)$

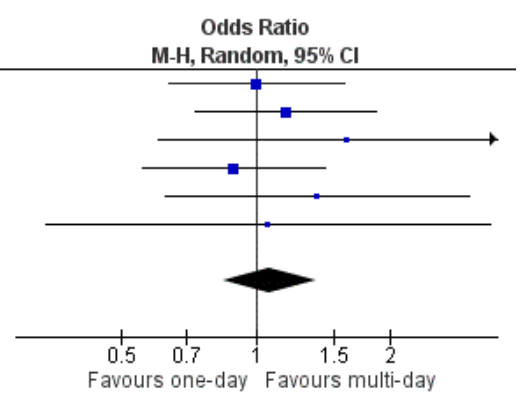

Figure 2 Efficacy of 1-day versus 3-day dexamethasone for the prophylaxis of chemotherapy-induced nausea and vomiting-complete response: (A) acute phase; (B) delayed phase; (C) overall phase.

interventions suggests that 1-day dexamethasone can achieve similar objectives as 3-day dexamethasone treatment, and can be administered as an alternative to the standard of care. For patients, this does not significantly decrease the cost of the treatment, as dexamethasone is over 22 times cheaper than other antiemetics (i.e., ondansetron, palonosetron) that are co-administered with the corticosteroid (26); the antiemetics will still be the cause of financial burden for CINV treatments. The transition to 1-day over 3-day treatment may also improve patient adherence. In fact, the latest American Society of Clinical Oncology's antiemetic guidelines suggests 1-day dexamethasone instead of 3-day dexamethasone for some patients receiving MEC (27).

There were limitations in this meta-analysis. There exists the possibility of a carry-over effect from acute phase data to delayed phase results, which is a reported and inherent limitation in the included RCTs (28). Additionally, this review only included seven RCTs in total, and hence some endpoints only have data on a few studies. The results of this review should be interpreted with caution and future RCTs are required to further compare the two dexamethasone treatment regimens.

In conclusion, 1-day dexamethasone seems to provide a similar efficacy and safety profile as 3-day dexamethasone in the prophylaxis of CINV. The similarities in efficacy and safety of the two interventions suggests that 1-day dexamethasone can be administered as an alternative to the standard of care. However, this review only includes six studies, of which five were studies recruiting only MEC patients. Further studies should continue to investigate whether these conclusions remain in the HEC setting. 


\begin{tabular}{|c|c|c|c|c|c|c|c|c|c|c|c|}
\hline \multirow[b]{2}{*}{ Study or Subgroup } & \multicolumn{2}{|c|}{ Dexamethasone multi-day } & \multicolumn{2}{|c|}{ Dexamethasone one-day } & \multicolumn{3}{|c|}{ Odds Ratio } & \multirow{2}{*}{\multicolumn{4}{|c|}{$\begin{array}{c}\text { Odds Ratio } \\
\text { M-H, Random, } 95 \% \mathrm{Cl}\end{array}$}} \\
\hline & Events & Total & Events & Total & Weight & M-H, Random, 95\% CI & Year & & & & \\
\hline Celio et al 2011 & 132 & 161 & 142 & 163 & $47.8 \%$ & $0.67[0.37,1.24]$ & 2011 & & & F & \\
\hline Matsuura et al 2015 & 52 & 53 & 54 & 56 & $3.0 \%$ & $1.93[0.17,21.89]$ & 2015 & & & & \\
\hline Furukawa et al 2015 & 37 & 39 & 39 & 43 & $5.8 \%$ & $1.90[0.33,10.98]$ & 2015 & & & & \\
\hline Komatsu et al 2015 & 142 & 154 & 141 & 151 & $23.4 \%$ & $0.84[0.35,2.01]$ & 2015 & & & & \\
\hline Kosaka et al 2016 & 26 & 41 & 28 & 39 & $20.0 \%$ & $0.68[0.27,1.75]$ & 2016 & & & & \\
\hline Total $(95 \% \mathrm{Cl})$ & & 448 & & 452 & $100.0 \%$ & $0.78[0.51,1.19]$ & & & & & \\
\hline Total events & 389 & & 404 & & & & & & & & \\
\hline \multicolumn{8}{|c|}{$\begin{array}{l}\text { Heterogeneity: } \mathrm{Tau}^{2}=0.00 ; \mathrm{Chi}^{2}=1.85, \mathrm{df}=4(\mathrm{P}=0.76) ; \mathrm{I}^{2}=0 \% \\
\text { Test for overall effect: } \mathrm{Z}=1.16(\mathrm{P}=0.24)\end{array}$} & $\frac{+}{0.1}$ & $\begin{array}{lc}0.2 & 0.5 \\
\text { Favours one-day }\end{array}$ & $\begin{array}{ccc}1 & 1 & 1 \\
& 2 & 5 \\
\text { Favours multi-day }\end{array}$ & $\frac{1}{10}$ \\
\hline \multirow[b]{2}{*}{ Study or Subgroup } & \multicolumn{2}{|c|}{ Dexamethasone multi-day } & \multicolumn{2}{|c|}{ Dexamethasone one-day } & \multicolumn{3}{|c|}{ Odds Ratio } & \multirow{2}{*}{\multicolumn{4}{|c|}{$\begin{array}{l}\text { Odds Ratio } \\
\text { M-H, Random, } 95 \% \mathrm{Cl}\end{array}$}} \\
\hline & Events & Total & Events & Total & Weight & M-H, Random, $95 \% \mathrm{Cl}$ & Year & & & & \\
\hline Celio et al 2011 & 122 & 161 & 108 & 163 & $33.7 \%$ & $1.59[0.98,2.59]$ & 2011 & & & & \\
\hline Komatsu et al 2015 & 97 & 154 & 99 & 151 & $36.1 \%$ & $0.89[0.56,1.43]$ & 2015 & & & & \\
\hline Matsuura et al 2015 & 36 & 53 & 33 & 56 & $12.9 \%$ & $1.48[0.67,3.24]$ & 2015 & & & & \\
\hline Furukawa et al 2015 & 28 & 39 & 29 & 43 & $8.9 \%$ & $1.23[0.48,3.16]$ & 2015 & & & & \\
\hline Kosaka et al 2016 & 28 & 41 & 29 & 39 & $8.4 \%$ & $0.74[0.28,1.97]$ & 2016 & & & & \\
\hline Total $(95 \% \mathrm{Cl})$ & & 448 & & 452 & $100.0 \%$ & $1.17[0.89,1.56]$ & & & & & \\
\hline Total events & 311 & & 298 & & & & & & & & \\
\hline \multicolumn{8}{|c|}{$\begin{array}{l}\text { Heterogeneity: } \text { Tau }^{2}=0.00 ; \mathrm{Chi}^{2}=4.00, \mathrm{df}=4(\mathrm{P}=0.41) ;\left.\right|^{2}=0 \% \\
\text { Test for overall effect: } Z=1.11(P=0.27)\end{array}$} & & $\begin{array}{cc}0.5 & 0.7 \\
\text { Favours one-day }\end{array}$ & 1.52 & \\
\hline \multirow[b]{2}{*}{ Study or Subgroup } & \multicolumn{2}{|c|}{ Dexamethasone multi-day } & \multicolumn{2}{|c|}{ Dexamethasone one-day } & \multicolumn{3}{|c|}{ Odds Ratio } & \multirow{2}{*}{\multicolumn{4}{|c|}{$\begin{array}{l}\text { Odds Ratio } \\
\text { M-H, Random, } 95 \% \mathrm{Cl}\end{array}$}} \\
\hline & Events & Total & Events & Total & Weight & M-H, Random, $95 \% \mathrm{Cl}$ & Year & & & & \\
\hline Celio et al 2011 & 109 & 161 & 105 & 163 & $35.4 \%$ & $1.16[0.73,1.83]$ & 2011 & & & $=$ & \\
\hline Matsuura et al 2015 & 36 & 53 & 33 & 56 & $12.2 \%$ & $1.48[0.67,3.24]$ & 2015 & & & & \\
\hline Furukawa et al 2015 & 28 & 39 & 28 & 43 & $8.5 \%$ & $1.36[0.53,3.48]$ & 2015 & & & & \\
\hline Komatsu et al 2015 & 95 & 154 & 98 & 151 & $34.5 \%$ & $0.87[0.55,1.39]$ & 2015 & & & & \\
\hline Kosaka et al 2016 & 20 & 41 & 24 & 39 & $9.5 \%$ & $0.60[0.24,1.45]$ & 2016 & & & & \\
\hline Total $(95 \% \mathrm{Cl})$ & & 448 & & 452 & $100.0 \%$ & $1.03[0.78,1.35]$ & & & & & \\
\hline Total events & 288 & & 288 & & & & & & & & \\
\hline $\begin{array}{l}\text { Heterogeneity: } \mathrm{Tau}^{2}= \\
\text { Test for overall effect: }\end{array}$ & $\begin{array}{l}0.00 ; \mathrm{Chi}^{2}=3.36 \\
=0.21(P=0.8\end{array}$ & $=0.5$ & $0) ; 1^{2}=0 \%$ & & & & & & $\begin{array}{cc}0.5 & 0.7 \\
\text { Favours one-day }\end{array}$ & Favours multi-day & \\
\hline
\end{tabular}

Figure 3 Efficacy of 1-day versus 3-day dexamethasone for the prophylaxis of chemotherapy-induced nausea and vomiting-complete control: (A) acute phase; (B) delayed phase; (C) overall phase.

\section{Acknowledgments}

Funding: None.

\section{Footnote}

Conflicts of Interest: All authors have completed the ICMJE uniform disclosure form (available at http://dx.doi. org/10.21037/jhmhp.2018.04.05). The authors have no conflicts of interest to declare.

Ethical Statement: The authors are accountable for all aspects of the work in ensuring that questions related to the accuracy or integrity of any part of the work are appropriately investigated and resolved.

Open Access Statement: This is an Open Access article distributed in accordance with the Creative Commons Attribution-NonCommercial-NoDerivs 4.0 International
License (CC BY-NC-ND 4.0), which permits the noncommercial replication and distribution of the article with the strict proviso that no changes or edits are made and the original work is properly cited (including links to both the formal publication through the relevant DOI and the license). See: https://creativecommons.org/licenses/by-nc-nd/4.0/.

\section{References}

1. Richardson JL, Marks G, Levine A. The influence of symptoms of disease and side effects of treatment on compliance with cancer therapy. J Clin Oncol 1988;6:174652.

2. Lindley CM, Hirsh JD, O'Neill CV, et al. Quality of life consequences of chemotherapy-induced emesis. Qual Life Res 1992;1:331-40.

3. Morita S, Kobayashi K, Eguchi K, et al. Influence of clinical parameters on quality of life during chemotherapy 
in patients with advanced non-small cell lung cancer:application of a general linear model. Jpn J Clin Oncol 2003;33:470-6.

4. Chiu L, Chow R, Popovic M, et al. Efficacy of olanzapine for the prophylaxis and rescue of chemotherapy-induced nausea and vomiting (CINV): a systematic review and meta-analysis. Support Care Cancer 2016;24:2381-92.

5. Osoba D, Zee B, Warr D, et al. Effect of postchemotherapy nausea and vomiting on health-related quality of life. Support Care Cancer 1997;5:307-13.

6. Chow R, Chiu L, Navari R, et al. Efficacy and safety of olanzapine for the prophylaxis of chemotherapy-induced nausea and vomiting (CINV) as reported in phase I and II studies:a systematic review. Support Care Cancer 2016;24:1001-8.

7. Chow R, Popovic M, Chiu L, et al. The combination of NK1 receptor antagonist, palonosetron, and dexamethasone compared to palonosetron and/or dexamethasone for the prophylaxis of chemotherapyinduced nausea and vomiting: A systematic review and meta-analysis of randomized controlled trials. J Pain Manag 2016;9:11-22.

8. Saito M, Aogi K, Sekine I, et al. Palonosetron plus dexamethasone versus granisetron plus dexamethasone for prevention of nausea and vomiting during chemotherapy:a double-blind, double-dummy, randomized, comparative phase III trial. Lancet Oncol 2009;10:115-24.

9. Diemunsch P, Grelot L. Potential of substance $P$ antagonists as anti-emetics. Drugs 2000;60:533-46.

10. Aapro M, Rugo H, Rossi G, et al. A randomized phase III study evaluating the efficacy and safety of NEPA, a fixeddosed combination of netupitant and palonosetron, for prevention of chemotherapy-induced nausea and vomiting following moderately emetogenic chemotherapy. Ann Oncol 2014;25:1328-33.

11. Ioannidis JP, Hesketh PJ, Lau J. Contribution of dexamethasone to control of chemotherapy-induced nausea and vomiting:a meta-analysis of randomized evidence. J Clin Oncol 2000;18:3409-22.

12. Roila F, Molassiotis A, Herrstedt J, et al. 2016 MASCC and ESMO guideline update for the prevention of chemotherapy- and radiotherapy-induced nausea and vomiting and of nausea and vomiting in advanced cancer patients. Ann Oncol 2016;27:v119-33.

13. Kosaka Y, Tanino H, Sengoku N, et al. Phase II randomized, controlled trial of 1 day versus 3 days of dexamethasone combined with palonosetron and aprepitant to prevent nausea and vomiting in Japanese breast cancer patients receiving anthracycline-based chemotherapy. Support Care Cancer 2016;24:1405-11.

14. Vardy J, Chiew KS, Galica J, et al. Side effects associated with the use of dexamethasone for prophylaxis of delayed emesis after moderately emetogenic chemotherapy. Br J Cancer 2006;94:1011-5.

15. Yeo W, Chan PK, Zhong S, et al. Frequency of hepatitis $\mathrm{B}$, virus reactivation in cancer patients undergoing cytotoxic chemotherapy:a prospective study of 626 patients with identification of risk factors. J Med Virol 2000;62:299-307.

16. Yeo W, Zee B, Zhong S, et al. Comprehensive analysis of risk factors associated with Hepatitis B virus (HBV) reactivation in cancer patients undergoing cytotoxic chemotherapy. Br J Cancer 2004;90:1306-11.

17. Aapro M, Fabi A, Nole F, et al. Double-blind, randomised, controlled study of the efficacy and tolerability of palonosetron plus dexamethasone for 1 day with or without dexamethasone on days 2 and 3 in the prevention of nausea and vomiting induced by moderately emetogenic chemotherapy. Ann Oncol 2010;21:1083-8.

18. Celio L, Frustaci S, Denaro A, et al. Palonosetron in combination with 1-day versus 3-day dexamethasone for prevention of nausea and vomiting following moderately emetogenic chemotherapy:a randomized, multicenter, phase III trial. Support Care Cancer 2011;19:1217-25.

19. Vardy J, Pond G, Dodd A, et al. A randomized doubleblind, placebo-controlled cross-over trial of the impact on quality of life of continuing dexamethasone beyond $24 \mathrm{~h}$ following adjuvant chemotherapy for breast cancer. Breast Cancer Res Treat 2012;136:143-51.

20. Furukawa N, Kanayama S, Tanase Y, et al. Palonosetron in combination with 1-day versus 3-day dexamethasone to prevent nausea and vomiting in patients receiving paclitaxel and carboplatin. Support Care Cancer 2015;23:3317-22.

21. Komatsu Y, Okita K, Yuki S, et al. Open-label, randomized, comparative, phase III study on effects of reducing steroid use in combination with palonosetron. Cancer Sci 2015;106:891-5.

22. Matsuura M, Satohisa S, Teramoto M, et al. Palonosetron in combination with 1-day versus 3-day dexamethasone for prevention of nausea and vomiting following paclitaxel and carboplatin in patients with gynecologic cancers:A randomized, multicenter, phase II trial. J Obstet Gynaecol Res 2015;41:1607-13.

23. Olver I, Paska W, Depierre A, et al. A multicenter, doubleblind study comparing placebo, ondansetron and ondansetron plus dexamethasone for the control of cisplatin-induced 
delayed emesis. Ann Oncol 1996;7:945-52.

24. Inoue A, Yamada Y, Matsumura Y, et al. Randomized study of dexamethasone treatment for delayed emesis, anorexia and fatigue induced by irinotecan. Support Care Cancer 2003;11:528-32.

25. Roscoe JA, Heckler CE, Morrow GR, et al. Prevention of delayed nausea:a University of Rochester Cancer Center Community Clinical Oncology Program study of patients receiving chemotherapy. J Clin Oncol 2012;30:3389-95.

doi: 10.21037/jhmhp.2018.04.05

Cite this article as: Chow R, Warr DG, Navari RM, Tsao M, Milakovic M, Popovic M, Chiu L, Lam H, DeAngelis C. Efficacy and safety of 1-day versus 3-day dexamethasone for the prophylaxis of chemotherapy-induced nausea and vomiting: a systematic review and meta-analysis of randomized controlled trials. J Hosp Manag Health Policy 2018;2:25.
26. Subramaniam B, Madan R, Sadhasivam S, et al. Dexamethasone is a cost-effective alternative to ondansetron in preventing PONV after pediatric strabismus repair. Br J Anaesth 2001;86:84-9.

27. Hesketh PJ, Kris MG, Basch E, et al. Antiemetics:American Society of Clinical Oncology Clinical Practice Guideline Update. J Clin Oncol 2017;35:3240-61.

28. Roila F, Donati D, Tamberi S, et al. Delayed emesis: incidence, pattern, prognostic factors and optimal treatment. Support Care Cancer 2002;10:88-95. 


\section{Supplementary}

\section{Appendix 1 Search strategy}

Database: Ovid MEDLINE(R) epub abead of print, in-process and other non-indexed citations, Ovid MEDLINE(R) Daily, Ovid MEDLINE and Versions(R) search strategy:

1. $\quad$ exp Neoplasms/ or (neoplasm or cancer).mp. [3423821]

2. palonosetron.mp. [566]

3. exp dexamethasone/ or dexamethasone.mp. [66470]

4. day.mp. [934734]

5. Comparative Study/ [1820429]

6. compar*.mp. [5489611]

7. (2 and 3) or (3 and (4 or 5 or 6$)$ ) [23252]

8. (chemotherapy adj5 induced adj5 nausea adj5 vomiting).mp. [1572]

9. CINV.mp. [731]

10. exp Nausea/ or (nausea or nauseous or nauseated).mp. [61685]

11. exp Vomiting/ or vomit*.mp. [30059]

12. or/8-11 [77890]

13. 1 and 7 and 12 [659]

14. limit 13 to randomized controlled trial [276]

15. ((randomized or randomised) adj5 (trial or controlled)).ti. [124122]

16. 13 and 15 [76]

17. 14 or 16 [281]

18. limit 17 to English language [260]

19. from 18 keep 1-260 [260]

Database: Embase Classic + Embase <1947 to 2017 Week 28> search strategy:

1. $\quad$ exp neoplasm/ [4092608]

2. exp palonosetron/ or palonosetron.mp. [1682]

3. exp dexamethasone/ or dexamethasone.mp. [146855]

4. day.mp. [1351637]

5. exp comparative study/ [1226778]

6. compar*.mp. [6862254]

7. (2 and 3) or (3 and (4 or 5 or 6$)$ ) [50891]

8. $\quad$ exp "chemotherapy induced nausea and vomiting"/ [2563]

9. (chemotherapy adj5 induced adj5 nausea adj5 vomiting).mp. [3882]

10. CINV.mp. [1463]

11. exp nausea/ or (nausea or nauseous or nauseated).mp. [243227]

12. exp vomiting/ or vomit*.mp. [234992]

13. or/8-12 [332334]

14. 1 and 7 and 13 [4222]

15. limit 14 to randomized controlled trial [603]

16. ((randomized or randomised) adj5 (trial or controlled)).ti. [146469]

17. 14 and 16 [208]

18. 15 or 17 [643]

19. limit 18 to English language [624] 
Database: EBM Reviews - Cochrane Central Register of Controlled Trials < fune 2017> search strategy:

1 exp Neoplasms/ or (neoplasm or cancer).mp. [103999]

2 palonosetron.mp. [305]

3 exp dexamethasone/ or dexamethasone.mp. [6812]

4 day.mp. [135221]

5 Comparative Study/ [8]

6 compar*.mp. [483121]

$7 \quad(2$ and 3$)$ or (3 and (4 or 5 or 6$)$ ) [4578]

8 (chemotherapy adj5 induced adj5 nausea adj5 vomiting).mp. [780]

9 CINV.mp. [359]

10 exp Nausea/ or (nausea or nauseous or nauseated).mp. [30381]

11 exp Vomiting/ or vomit*.mp. [22883]

12 or/8-11 [34715]

$13 \quad 1$ and 7 and 12 [620]

14 limit 13 to English language [526] 


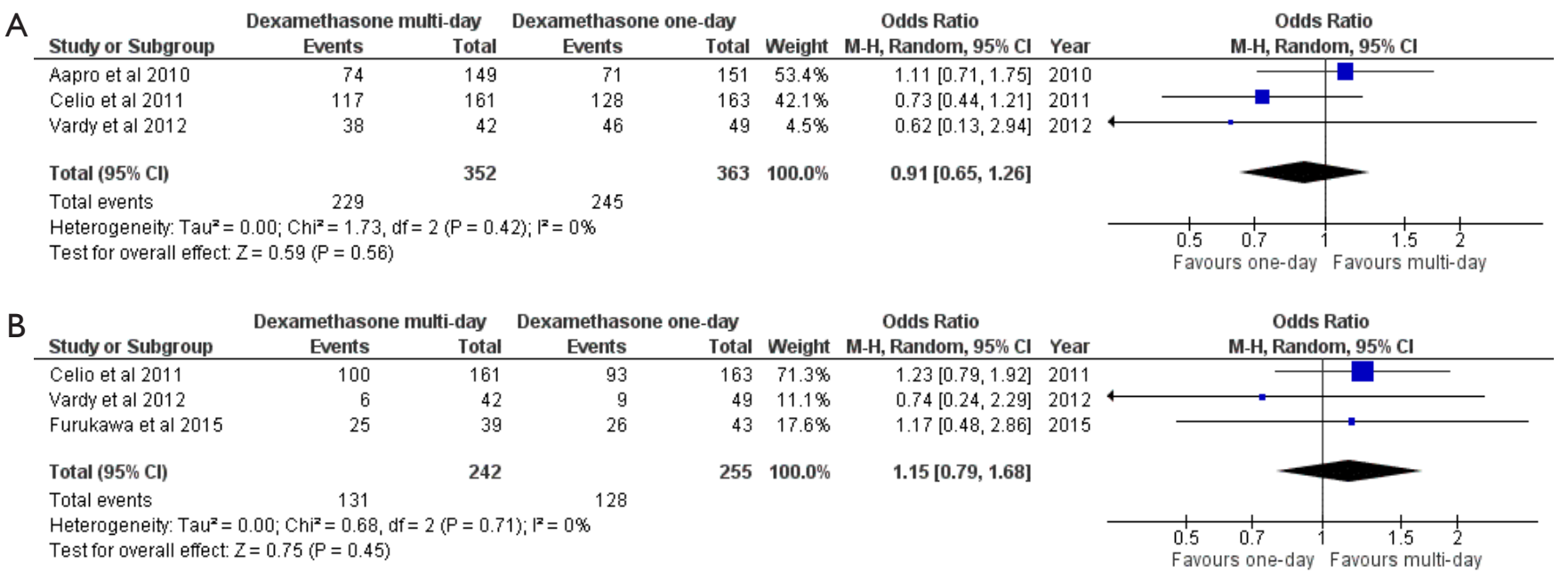

Figure S1 Efficacy of 1-day versus 3-day dexamethasone for the prophylaxis of chemotherapy-induced nausea and vomiting-no nausea. (A) acute phase; (B) delayed phase. 


\begin{tabular}{|c|c|c|c|c|c|c|c|c|c|c|}
\hline \multirow[t]{8}{*}{ A } & & \multicolumn{2}{|c|}{ Dexamethasone multi-day } & \multicolumn{2}{|c|}{ Dexamethasone one-day } & \multicolumn{3}{|c|}{ Odds Ratio } & \multirow{2}{*}{\multicolumn{2}{|c|}{$\begin{array}{c}\text { Odds Ratio } \\
\text { M-H, Random, } 95 \% \mathrm{Cl}\end{array}$}} \\
\hline & Study or Subgroup & Events & Total & Events & Total & Weight & M-H, Random, $95 \% \mathrm{Cl}$ & Year & & \\
\hline & Aapro et al 2010 & 118 & 149 & 121 & 151 & $67.0 \%$ & $0.94[0.54,1.66]$ & 2010 & 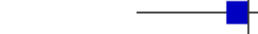 & \\
\hline & Celio et al 2011 & 148 & 161 & 153 & 163 & $29.0 \%$ & $0.74[0.32,1.75]$ & 2011 & & \\
\hline & Vardy et al 2012 & 41 & 42 & 46 & 49 & $4.0 \%$ & $2.67[0.27,26.72]$ & 2012 & & \\
\hline & Total $(95 \% \mathrm{Cl})$ & & 352 & & 363 & $100.0 \%$ & $0.92[0.58,1.46]$ & & & \\
\hline & Total events & 307 & & 320 & & & & & & \\
\hline & $\begin{array}{l}\text { Heterogeneity: Tau }{ }^{2}= \\
\text { Test for overall effect: }\end{array}$ & $\begin{array}{l}0.00 ; C^{2}=1.0 \\
Z=0.36(P=0.7\end{array}$ & $P=0.5$ & $59 ; P^{2}=0 \%$ & & & & & $\begin{array}{ccc}0.5 & 0.7 & 1 \\
\text { Favours one-day }\end{array}$ & $\begin{array}{c}1.52 \\
\text { Favours multi-day }\end{array}$ \\
\hline \multirow[t]{8}{*}{ B } & & \multicolumn{2}{|c|}{ Dexamethasone multi-day } & \multicolumn{2}{|c|}{ Dexamethasone one-day } & \multicolumn{3}{|c|}{$\begin{array}{l}\text { Odds Ratio } \\
\text {. }\end{array}$} & \multirow{2}{*}{\multicolumn{2}{|c|}{$\begin{array}{c}\text { Odds Ratio } \\
\text { M-H, Random, } 95 \% \mathrm{Cl}\end{array}$}} \\
\hline & Study or Subgroup & Events & Total & Events & Total & Weight & M-H, Random, $95 \% \mathrm{Cl}$ & Year & & \\
\hline & Aapro et al 2010 & 127 & 149 & 119 & 151 & $48.6 \%$ & $1.55[0.85,2.82]$ & 2010 & & $\square$ \\
\hline & Celio et al 2011 & 145 & 161 & 140 & 163 & $37.7 \%$ & $1.49[0.76,2.94]$ & 2011 & & \\
\hline & Vardy et al 2012 & 6 & 42 & 9 & 49 & $13.7 \%$ & $0.74[0.24,2.29]$ & 2012 & & \\
\hline & Total $(95 \% \mathrm{Cl})$ & & 352 & & 363 & $100.0 \%$ & $1.38[0.91,2.10]$ & & & \\
\hline & Total events & 278 & & 268 & & & & & & \\
\hline & $\begin{array}{l}\text { Heterogeneity: Tau }{ }^{2}= \\
\text { Test for overall effect: }\end{array}$ & $\begin{array}{l}0.00 ; \mathrm{Chi}^{2}=1.3 \\
Z=1.52(P=0.1\end{array}$ & $P=0.5$ & $50) ; 1^{2}=0 \%$ & & & & & $\begin{array}{cc}0.5 & 0.7 \\
\text { Favours one-day }\end{array}$ & $\begin{array}{c}1.52 \\
\text { Favours multi-day }\end{array}$ \\
\hline \multirow[t]{7}{*}{ C } & & \multicolumn{2}{|c|}{ Dexamethasone multi-day } & \multicolumn{2}{|c|}{ Dexamethasone one-day } & & Odds Ratio & & \multirow{2}{*}{\multicolumn{2}{|c|}{$\begin{array}{c}\text { Odds Ratio } \\
\text { M-H, Random, } 95 \% \mathrm{Cl}\end{array}$}} \\
\hline & Study or Subgroup & Events & Total & Events & Total & Weight & M-H, Random, $95 \% \mathrm{Cl}$ & Year & & \\
\hline & Aapro et al 2010 & 108 & 149 & 108 & 151 & $57.0 \%$ & $1.05[0.63,1.74]$ & 2010 & & \\
\hline & Celio et al 2011 & 135 & 161 & 134 & 163 & $43.0 \%$ & $1.12[0.63,2.01]$ & 2011 & & \\
\hline & Total $(95 \% \mathrm{Cl})$ & & 310 & & 314 & $100.0 \%$ & $1.08[0.74,1.58]$ & & & \\
\hline & Total events & 243 & & 242 & & & & & & \\
\hline & $\begin{array}{l}\text { Heterogeneity: Tau }{ }^{2}= \\
\text { Test for overall effect: }\end{array}$ & $\begin{array}{l}0.00 ; \mathrm{Chi}^{2}=0.0 \\
Z=0.40(P=0 .\end{array}$ & $P=0.8$ & $36) ; I^{2}=0 \%$ & & & & & Favours one-day ${ }^{1}$ & $\begin{array}{c}1.5 \\
\text { Favours multi-day }\end{array}$ \\
\hline
\end{tabular}

Figure S2 Efficacy of 1-day versus 3-day dexamethasone for the prophylaxis of chemotherapy-induced nausea and vomiting-no emesis. (A) acute phase; (B) delayed phase; (C) overall phase.

\begin{tabular}{|c|c|c|c|c|c|c|c|c|c|c|}
\hline \multirow{2}{*}{ A } & \multirow[b]{2}{*}{ Study or Subgroup } & \multicolumn{2}{|c|}{ Dexamethasone multi-day } & \multicolumn{2}{|c|}{ Dexamethasone one-day } & \multicolumn{3}{|c|}{ Odds Ratio } & \multirow{2}{*}{\multicolumn{2}{|c|}{$\begin{array}{c}\text { Odds Ratio } \\
\text { M-H, Random, } 95 \% \mathrm{Cl}\end{array}$}} \\
\hline & & Events & Total & Events & Total & Weight & M-H, Random, 95\% Cl & Year & & \\
\hline & Celio et al 2011 & 134 & 161 & 119 & 163 & $81.7 \%$ & $1.84[1.07,3.15]$ & 2011 & & \\
\hline & Furukawa et al 2015 & 33 & 39 & 34 & 43 & $18.3 \%$ & $1.46[0.47,4.55]$ & 2015 & & \\
\hline & Total $(95 \% \mathrm{Cl})$ & & 200 & & 206 & $100.0 \%$ & $1.76[1.08,2.86]$ & & & \\
\hline & Total events & 167 & & 153 & & & & & & \\
\hline & $\begin{array}{l}\text { Heterogeneity: } \mathrm{Tau}^{2}= \\
\text { Test for overall effect: }\end{array}$ & $\begin{array}{l}00 ; \mathrm{Chi}^{2}=0.13, \\
=2.27(\mathrm{P}=0.02)\end{array}$ & $P=0.72$ & $2 ;\left.\right|^{2}=0 \%$ & & & & & $\begin{array}{cc}0.5 & 0.7 \\
\text { Favours one-day }\end{array}$ & $\begin{array}{c}1.52 \\
\text { Favours multi-day }\end{array}$ \\
\hline \multirow[t]{7}{*}{ B } & & Dexamethason & i-day & Dexamethaso & -day & & Odds Ratio & & Odds F & Ratio \\
\hline & Study or Subgroup & Events & Total & Events & Total & Weight & M-H, Random, 95\% Cl & Year & M-H, Randol & $\mathrm{om}, 95 \% \mathrm{Cl}$ \\
\hline & Celio et al 2011 & 129 & 161 & 116 & 163 & $83.0 \%$ & $1.63[0.98,2.73]$ & 2011 & & \\
\hline & Furukawa et al 2015 & 33 & 39 & 34 & 43 & $17.0 \%$ & $1.46[0.47,4.55]$ & 2015 & & \\
\hline & Total $(95 \% \mathrm{Cl})$ & & 200 & & 206 & $100.0 \%$ & $1.60[1.00,2.56]$ & & & \\
\hline & Total events & 162 & & 150 & & & & & & \\
\hline & $\begin{array}{l}\text { Heterogeneity: } \operatorname{Tau}^{2}= \\
\text { Test for overall effect: }\end{array}$ & $\begin{array}{l}00 ; \mathrm{Chi}^{2}=0.03, \\
=1.97(P=0.05)\end{array}$ & $P=0.86$ & $6) ;\left.\right|^{2}=0 \%$ & & & & & $\begin{array}{cc}0.5 & 0.7 \\
\text { Favours one-day }\end{array}$ & $\begin{array}{c}1.52 \\
\text { Favours multi-day }\end{array}$ \\
\hline
\end{tabular}

Figure S3 Efficacy of 1-day versus 3-day dexamethasone for the prophylaxis of chemotherapy-induced nausea and vomiting-no use of rescue medication. (A) delayed phase; (B) overall phase. 


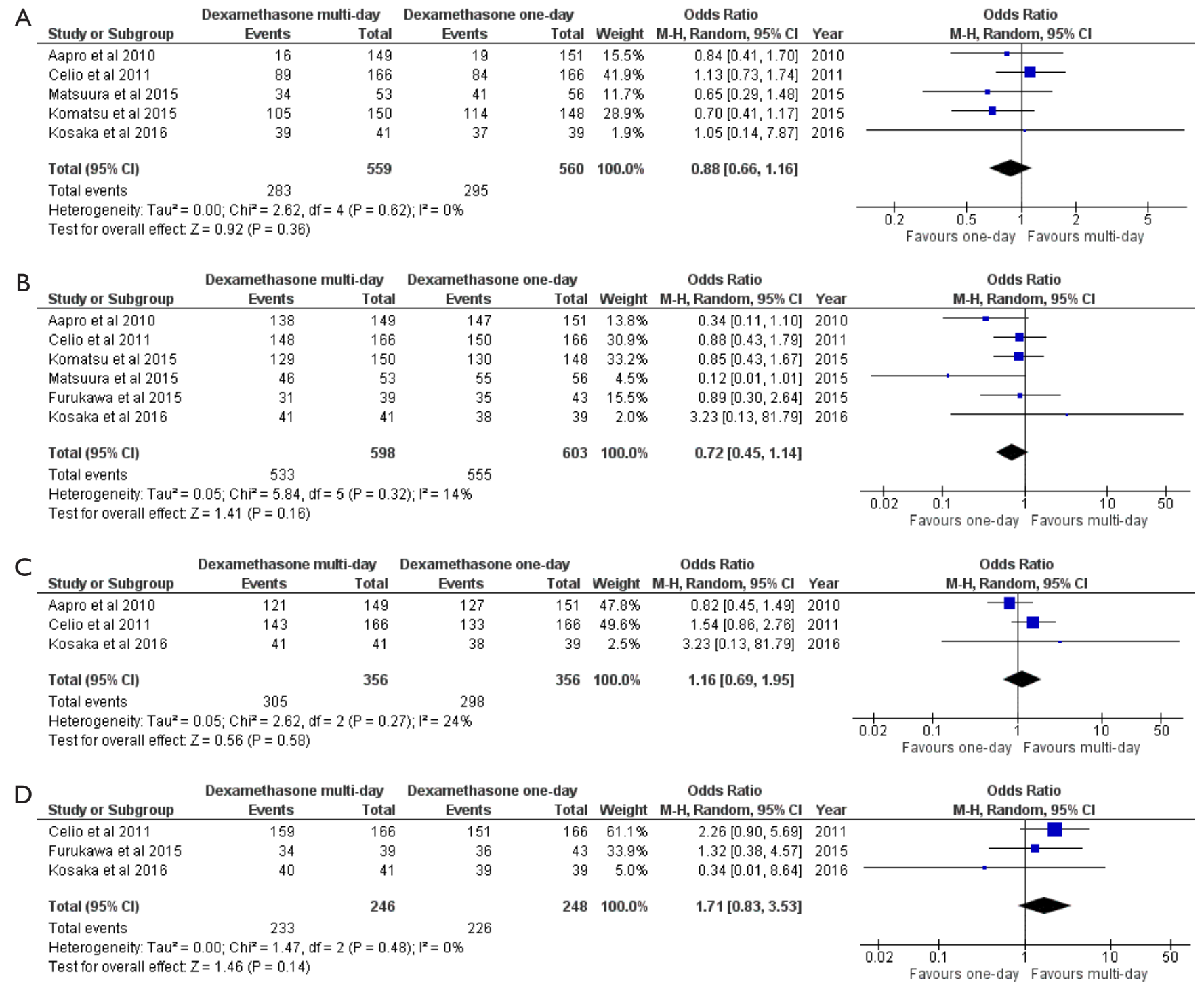

Figure S4 Safety of 1-day versus 3-day dexamethasone for the prophylaxis of chemotherapy-induced nausea and vomiting. (A) no adverse events; (B) no constipation; (C) no headache; (D) no fatigue/insomnia. 